\title{
Shoot growth restriction in dry matter partitioning and minituber production of potato plants
}

\author{
Restrição do crescimento da parte aérea na partição de \\ assimilados e produtividade de minitubérculos de batata
}

\author{
Dilson Antônio Bisognin ${ }^{\mathrm{I}}$ Jacso Dellai ${ }^{\mathrm{II}}$
}

\section{ABSTRACT}

The aim of this research was to determine the effect of shoot growth restriction in the dry matter partitioning and minituber production of potato plants grown in a closed soilless system. Minitubers of the cultivars 'Macaca' and 'Asterix'were planted in the greenhouse in the density of 100 hills $\mathrm{m}^{-2}$, during autumn and spring growing seasons. Growth restriction levels were gotten by pruning shoots at 10, 20 and 30cm height or without pruning. The growth restriction levels were identified by their respective leaf area index. The experiment was a factorial (cultivars $x$ growth restriction $x$ growing season) in a random design, with four replications. Growth restriction affected the dry matter production of potato plants in both growing seasons and cultivars. Pruning potato plants at $30 \mathrm{~cm}$ is a feasible technique to control leaf area index and it has lower effect on harvest index and number than in dry matter production of minitubers. Growth restriction does not change dry matter partitioning of potato plants grown in soilless system.

Key words: Solanum tuberosum L., leaf area, plant propagation, cuttings, tuber seeds.

\section{RESUMO}

$O$ objetivo deste trabalho foi determinar o efeito da restrição do crescimento da parte aérea pela poda verde, na partição de matéria seca das plantas e na produtividade de minitubérculos de batata em sistema fechado de cultivo sem solo. Minitubérculos das cultivares 'Macaca'e 'Asterix' foram plantados em telado na densidade de 100 covas $m^{-2}$ nos cultivos de outono e primavera. As restrições do crescimento da parte aérea foram obtidas pela poda verde aos 10, 20 e $30 \mathrm{~cm}$ de altura e uma testemunha sem restrição. Os níveis de restrição do crescimento foram identificados pelos respectivos índices de área foliar. $O$ experimento foi conduzido em um fatorial (cultivares $x$ restrição do crescimento $x$ épocas de cultivo) no delineamento inteiramente casualizado, com quatro repetições. A restrição do crescimento da parte aérea afetou a produção de matéria seca das plantas de batata de ambas cultivares é épocas de cultivo. A poda verde a $30 \mathrm{~cm}$ de altura é uma técnica eficaz para controlar o indice de área foliar e tem menor efeito no índice de colheita e no número do que na produção de matéria seca de minitubérculos. A restrição do crescimento da parte aérea não altera a partição de matéria seca das plantas de batata no cultivo sem solo.

Palavras-chave: Solanum tuberosum L., área foliar, propagação de plantas, miniestacas, tubérculos-semente.

\section{INTRODUCTION}

Recent technological advances in potato (Solanum tuberosum L.) propagation increased the availability of pathogen-free seed stocks. Greenhouse-grown tubers, tissue culture plantlets, and rooted stem cuttings are used for the production of pre-basic minitubers. The minituber production in soilless cultivation systems is an important tool to achieve high multiplication rates and physiological quality of disease free plantlets. Closed soilless systems, as aeroponic (ROLOT\&SEUTIN, 1999; RITTER et al., 2001), deep flow technique (DFT), nutrient film technique (NFT) (MEDEIROS et al., 2002), and inert substrate were developed for potato minituber production. A common feature of these soilless systems is the high shoot growth that increases the consumption of nutrient solution. Values of leaf area index (LAI) up to 24 were gotten in potato

\footnotetext{
IDepartamento de Fitotecnia, Universidade Federal de Santa Maria (UFSM), Camobi, 97105-900, Santa Maria, RS, Brasil. E-mail: dilson.bisognin@ufsm.br. Corresponding author.

IIDu Pont do Brasil S.A., Divisão Pioneer Sementes, Estação de Pesquisa de Coxilha, Passo Fundo, RS, Brasil.
} 
plants of the cultivar 'Macaca' during spring season (MÜLLER et al., 2007). Therefore, management techniques to control shoot growth and increase dry matter partitioning to the tubers are necessary to increase harvest index and multiplication rates.

Vegetative growth can increase yield of agricultural crops until LAI reaches the maximum interception of solar radiation, when the net photosynthesis rate on LAI base becomes small or null (GULÍAS et al., 2003). In potatoes, the rate of solar radiation interception increased linearly until LAI of 2.25 and at reduced rates until LAI of 4.0 (KHURANA \& MCLAREN, 1982). In field conditions, potato plants reached maximum LAI between 3.0 and 4.0 (OLIVEIRA et al., 2000) and 6.0 (WRIGHT \& STARK, 1990). A LAI of 4.0 intercepted about $95 \%$ of the solar radiation and between 3.5 and 4.5 achieved the maximum dry matter production (KHURANA \& MCLAREN, 1982).

Environmental conditions, as high availability of water and nutrients and temperatures in the range of 15 and $19^{\circ} \mathrm{C}$, favor shoot growth, delay tuber initiation and reduce dry matter partitioning to the tubers (KHEDHER \& EWING, 1985; VAN DAM et al., 1996). These are typical conditions of soilless cultivation systems, because of the optimization of water and nutrient availability by fertirrigation and the increase of temperature as a result of the greenhouse effect. However, stress conditions may reduce the duration of developmental phases and dry matter partitioning. Shoot growth restriction by pruning is a technique that has been used in other horticultural crops to fix and increase quality and dry matter partitioning to the fruits (SANDRI et al., 2002; TREVISAN et al., 2006). As far as it is known, there is no information about pruning potato plants to control and restrict shoot growth in soilless systems, which is necessary to reduce nutrient solution consumption and chemicals usage to control foliar diseases with benefits for minituber production and quality. The aim of this research was to determine the effect of shoot growth restriction in the dry matter partitioning and minituber production of potato plants grown in a closed soilless system with sand as substrate.

\section{MATERIAL AND METHODS}

The experiment was carried out in a greenhouse, covered on top with a film of low density polyethylene and sides with an anti-aphid screen, of the Plant Breeding and Asexual Propagation Center, Department of Plant Sciences of the Universidade
Federal de Santa Maria, RS (latitudeof 29 42', longitude of $53^{\circ} 48^{\prime} \mathrm{W}$ and altitude of $95 \mathrm{~m}$ ). Potato plants were grown in a closed soilless system with coarse sand as substrate (BANDINELLI et al., 2013). Sand particles had diameter between 0.1 and $0.3 \mathrm{~cm}$, density of $1.6 \mathrm{~kg} \mathrm{dm}^{3}$ and maximum volume of retained water of $0.111 \mathrm{~L} \mathrm{dm}^{3}$. A standard nutrient solution was employed with the following composition $\left(\mathrm{mg} \mathrm{L}^{-1}\right)$ : 149.80 of $\mathrm{NO}_{3} ; 24.80$ of $\mathrm{H}_{2} \mathrm{PO}_{4}^{-} ; 39.27$ of $\mathrm{SO}_{4}^{--} ; 41.31$ of $\mathrm{Mg}^{++} ; 288.72$ of $\mathrm{Ca}^{++} ; 234.60$ of $\mathrm{K}^{+}$and electrical conductivity (EC) of $2.5 \mathrm{dS} \mathrm{m}^{-1}$. Micronutrients were provided in the concentrations $\left(\mathrm{mg} \mathrm{L}^{-1}\right)$ : 0.03 of Mo; 0.42 of $\mathrm{B} ; 0.06$ of $\mathrm{Cu} ; 0.50$ of $\mathrm{Mn} ; 0.22$ of $\mathrm{Zn}$ and 1.0 of Fe. The fertirrigations were made twice a day ( 9 a.m. and 4 p.m.), during the first three weeks after planting, and four times a day (9 a.m. and 1, 4 and 6 p.m.), until the end of the experiment. The fertirrigations were automated by a timer and lasted $15 \mathrm{~min}$.

The experiment was carried out with the potato cultivars 'Macaca' and 'Asterix' during autumn and spring growing seasons. Minitubers from micropropagated plantlets with diameter between 5 and $10 \mathrm{~mm}$ were planted in the density of 100 hills per $\mathrm{m}^{2}$. Shoot growth restriction by pruning was applied twice a week to keep plant height at 10,20 and $30 \mathrm{~cm}$ throughout the experimental period. The control plants did not receive shoot pruning. The experiment was a factorial (cultivar $\mathrm{x}$ growth restriction $\mathrm{x}$ growing season) in a random design, with four repetitions of ten rows of $1.0 \mathrm{~m}$. The border row and one plant of each row were discarded before evaluations.

The maximum LAI was estimated at the beginning of senescence of control plants. Ten plants of each treatment were harvested and determined the dry matter of shoots. The LAI was estimated based upon the relationship between dry matter and leaf area of 30 discs $\left(0.5026 \mathrm{~cm}^{2}\right)$ from leaves that represent different parts of the canopy. The growth restriction levels by pruning the plants at 10, 20 and $30 \mathrm{~cm}$ and the control (without shoot pruning) were identified by their respective LAI. The estimated LAI of each treatment was used to study the effect of shoot growth restriction in the dry matter partitioning and minituber production, because of the direct correlation among LAI, photosynthetic rates and yield (KHEDHER \& EWING, 1985).

The experiment was finished when the control plants had approximately $50 \%$ of senescent leaves. In each plot, it was counted the number of plants and quantified the above ground dry matter. Minitubers were harvest, counted and fresh weight quantified. Dry matter was estimated in a sample of 10 minitubers, representative of each plot, used to estimate the dry matter of tubers. Harvest index represented the tuber 
fraction of the total dry matter production. All dry matter determinations were done drying the samples in a forced air oven at $60^{\circ} \mathrm{C}$ until constant weight.

The global solar radiation in the greenhouse was estimated according to the Ångstron model, adjusted to Santa Maria (ESTEFANEL et al., 1990) and to the experimental conditions (BURIOL et al., 1995). The temperature and solar radiation data were gotten from the main climatological station, about $100 \mathrm{~m}$ from the greenhouse. Data were submitted to variance analysis and treatment means compared by either Tukey or polynomial regression, at $5 \%$ of error probability.

\section{RESULTS AND DISCUSSION}

Solar radiation varied between growing seasons in the greenhouse. The daily average was 7.15 and $10.46 \mathrm{MJ} \mathrm{m}^{-2}$ day $^{-1}$, and the cumulative irradiation was 572.13 and $826.14 \mathrm{MJ} \mathrm{m}^{-2}$, respectively for autumn and spring seasons. In autumn, the average daily air temperature was $20.1^{\circ} \mathrm{C}$ and spring season was $18.7^{\circ} \mathrm{C}$. Daily air temperature variation was similar between growing seasons, with the average of $9.9^{\circ} \mathrm{C}$ during autumn and $10.1^{\circ} \mathrm{C}$ during spring.

There was interaction among growing season, growth restriction levels and cultivars for all studied traits. The spring growing season showed the highest LAI and total dry matter production (Table 1). Differences between cultivars were found during autumn, when 'Asterix' had the highest LAI and 'Macaca' the highest total dry matter production. The cultivar 'Asterix' was affected by the growing season in terms of tuber production. 'Asterix' had the smallest tuber number in autumn and the lowest tuber dry matter in spring season.

Shoot growth restriction by pruning to keep plant height at 10,20 and $30 \mathrm{~cm}$ and the control (without shoot pruning) resulted, respectively for 'Macaca' and 'Asterix' cultivars, in the LAI of $2.2 ; 2.8 ; 3.4$ and 7.5 and $2.3 ; 4.1 ; 4.8$ and 9.3 during autumn, and $2.2 ; 5.1 ; 6.2$ and 16.4 and 3.5 ; 5.1; 6.8 and 17.5, during spring (Figures 1, 2 and 3). Differences in the LAI of the same treatment between seasons are probably associated to air temperature and solar radiation, which increase during spring and decrease during autumn with plant development. Therefore, spring has environmental conditions that favor shoot growth (MARINUS \& BODLAENDER, 1975). These favorable conditions resulted in high rates of assimilate production during tuberization phase, which may have minimized the competition between shoot growth and minituber production during spring. On the other hand, autumn growing conditions should increase competition between shoot and minituber and resulted in the lowest LAI and total dry matter production of both cultivars (Table 1).

Growth restriction affected the dry matter production of potato plants in both growing seasons and cultivars (Figure 1). A linear relationship between LAI and dry matter production of potato plants was found during spring season, showing that shoot continued being an important sink even after tuber initiation and growth. In autumn, the LAI increment from 4.8 to 9.3 increased the total dry matter production in about $20 \%$ of the cultivar 'Asterix'. Control plants showed a high production of total dry matter during spring, almost twice as the production during autumn season. However, the total dry matter production was determined primarily by the high fraction of shoot instead of tuber, because of favorable conditions of air temperature and solar radiation to shoot growth, that reduce dry matter partitioning to the tubers (EWING, 1981; KHEDHER \& EWING, 1985; VAN DAM et al., 1996).

Table 1 - Leaf area index, total $\left(\mathrm{g} \mathrm{m}^{-2}\right)$ and tuber $(\mathrm{mg})$ dry matter, and number of tubers per $\mathrm{m}^{2}$ of potato plants of 'Macaca' and 'Asterix' cultivars submitted to different levels of vegetative growth restriction in two growing seasons in a closed soilless system.

\begin{tabular}{|c|c|c|c|c|}
\hline \multirow{2}{*}{ Cultivars } & \multirow{2}{*}{ Leaf area índex } & 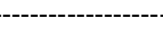 & - & \multirow{2}{*}{ Number of tubers per $\mathrm{m}^{2}$} \\
\hline & & Total $\left(\mathrm{g} \mathrm{m}^{-2}\right)$ & Tubers (mg) & \\
\hline & $4.01 \mathrm{bB}^{*}$ & $719.7 \mathrm{aB}$ & $142.0 \mathrm{aA}$ & $291.6 \mathrm{aA}$ \\
\hline 'Asterix' & $5.14 \mathrm{aB}$ & $559.2 \mathrm{bB}$ & $132.0 \mathrm{aA}$ & $225.7 \mathrm{bA}$ \\
\hline 'Macaca' & $7.46 \mathrm{aA}$ & $1079.7 \mathrm{aA}$ & $104.0 \mathrm{aA}$ & $201.4 \mathrm{aB}$ \\
\hline 'Asterix' & $8.24 \mathrm{aA}$ & $1080.1 \mathrm{aA}$ & $88.0 \mathrm{bB}$ & $223.4 \mathrm{aA}$ \\
\hline CV\% & 25.3 & 17.1 & 12.9 & 9.9 \\
\hline
\end{tabular}

*Averages followed by the same letter, low case for cultivars and capital for growing seasons, do not differ by the Tukey test $(\mathrm{P}<0.05)$. 


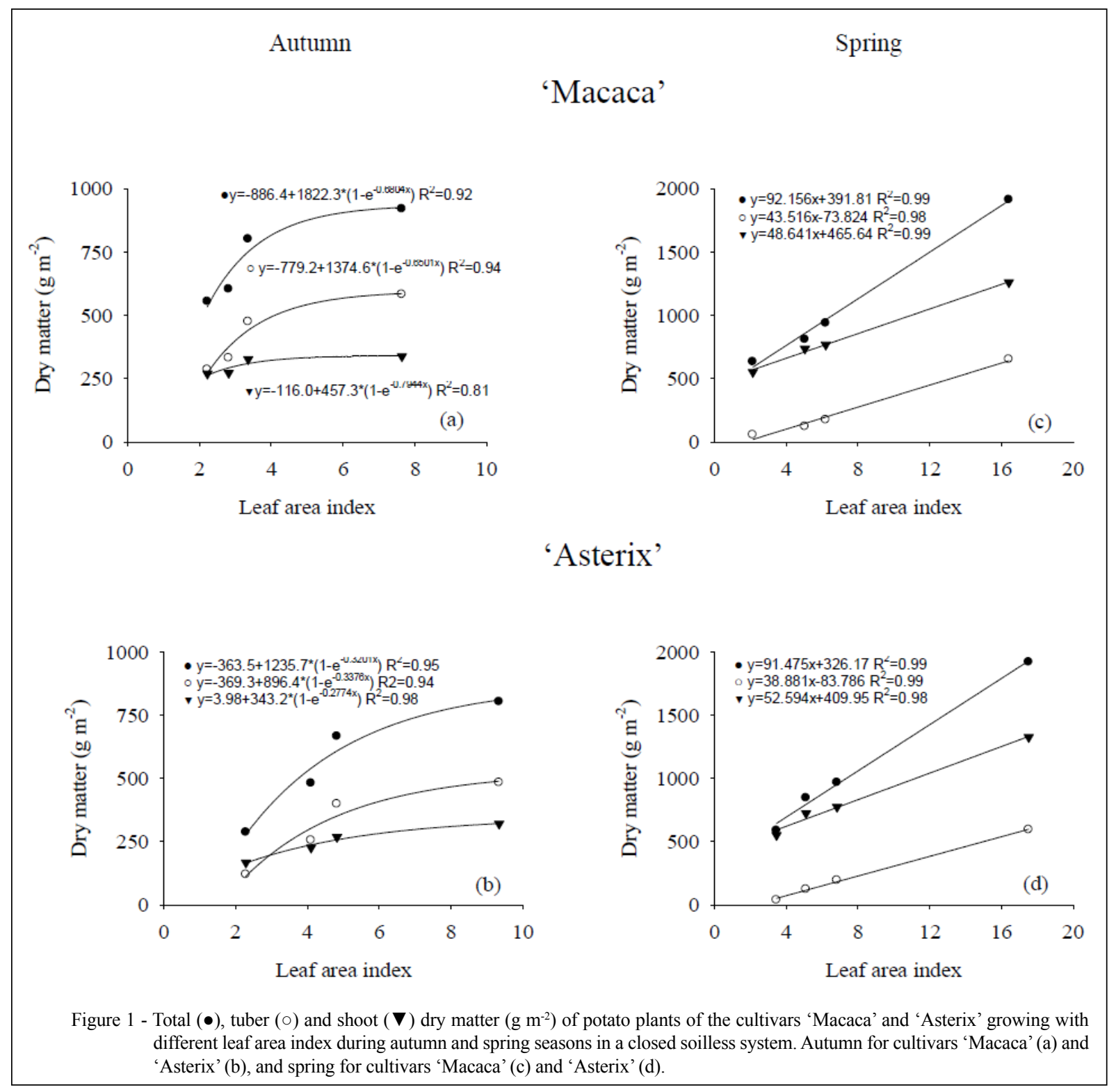

Autumn resulted in higher harvest index (about 0.6) than spring (about 0.2) (Figure 2). As the dry matter production of minitubers was similar in spring and autumn growing seasons (Figure 1), the major difference between autumn and spring was the high dry matter production of shoots, which resulted in lower harvest index. The application of growth restriction by pruning plants at $30 \mathrm{~cm}$ height had almost no affect on harvest index during autumn. During spring, both cultivars were affected by shoot pruning and 'Macaca' showed a linear response between harvest index and LAI. As higher temperature produced more shoots than tubers (MARINUS \& BODLAENDER, 1975), pruning during spring should increase assimilate partitioning to sustain vegetative growth. These differences in dry matter partitioning are in agreement with EWING (1981) that found genetic diversity for dry matter partitioning and that high temperatures and long days decreased assimilate partitioning to tubers. Therefore, harvest index of potato plants growing in soilless system varied between seasons and it was affected by shoot growth restriction during spring.

The shoot growth restriction affected the average dry matter of minituber in both growing seasons (Figure 3). With the exception of the cultivar 'Macaca' during spring, pruning potato plants at $30 \mathrm{~cm}$

Ciência Rural, v.45, n.11, nov, 2015. 


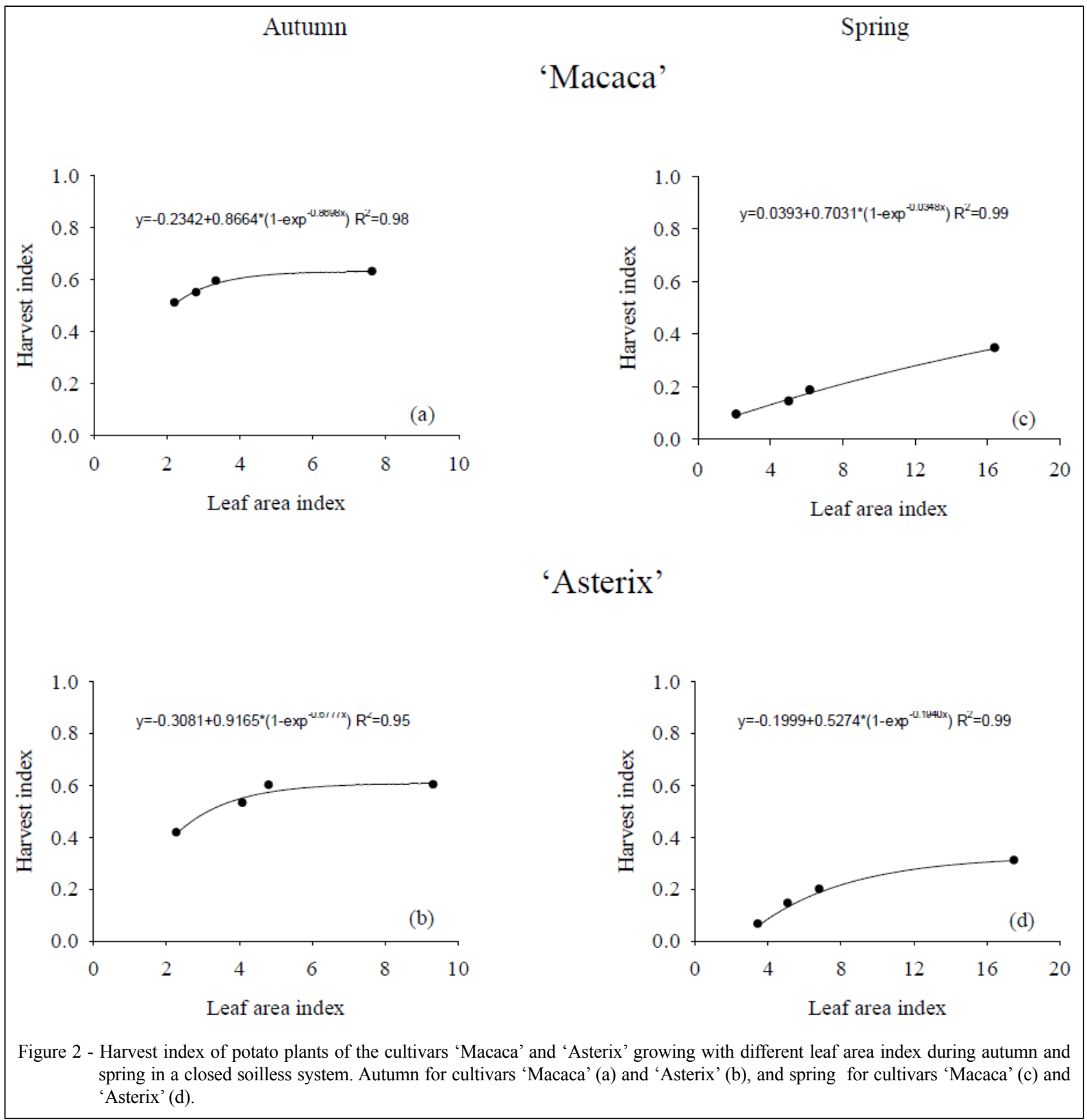

height almost had no effect on minituber number. A linear relationship was found between the average dry matter of minitubers (size) and LAI during spring season. Therefore, increasing LAI was more effective to increase the size than the number of minitubers. In potato minituber production, size is less important than number, because the multiplication rate of pathogenfree plantlets is the major goal. These results are in disagreement with ESCOBAR \& VANDER ZAAG (1988) that found no effect on branching, canopy cover or tuber yield by pruning apical shoot of field growing potato plants.
The efficiency of conversion solar radiation in total dry matter (DM) production was $1.57 \mathrm{~g}$ DM $\mathrm{MJ}^{-1}$ during autumn and 2.41g DM $\mathrm{MJ}^{-1}$ during spring season. Considering only the dry matter production of minitubers, the efficiency of conversion was $0.87 \mathrm{~g}$ $\mathrm{DM} \mathrm{MJ}^{-1}$ during autumn and $0.60 \mathrm{~g} \mathrm{DM} \mathrm{MJ}^{-1}$ during spring season. Therefore, different responses in dry matter production between autumn and spring season could be explained by the radiation use efficiency (RUE). In autumn season, RUE presented a higher increment rate until LAI of 3.4 and 4.8, respectively for 'Macaca' and 'Asterix' cultivars (Figure 4). In spring 


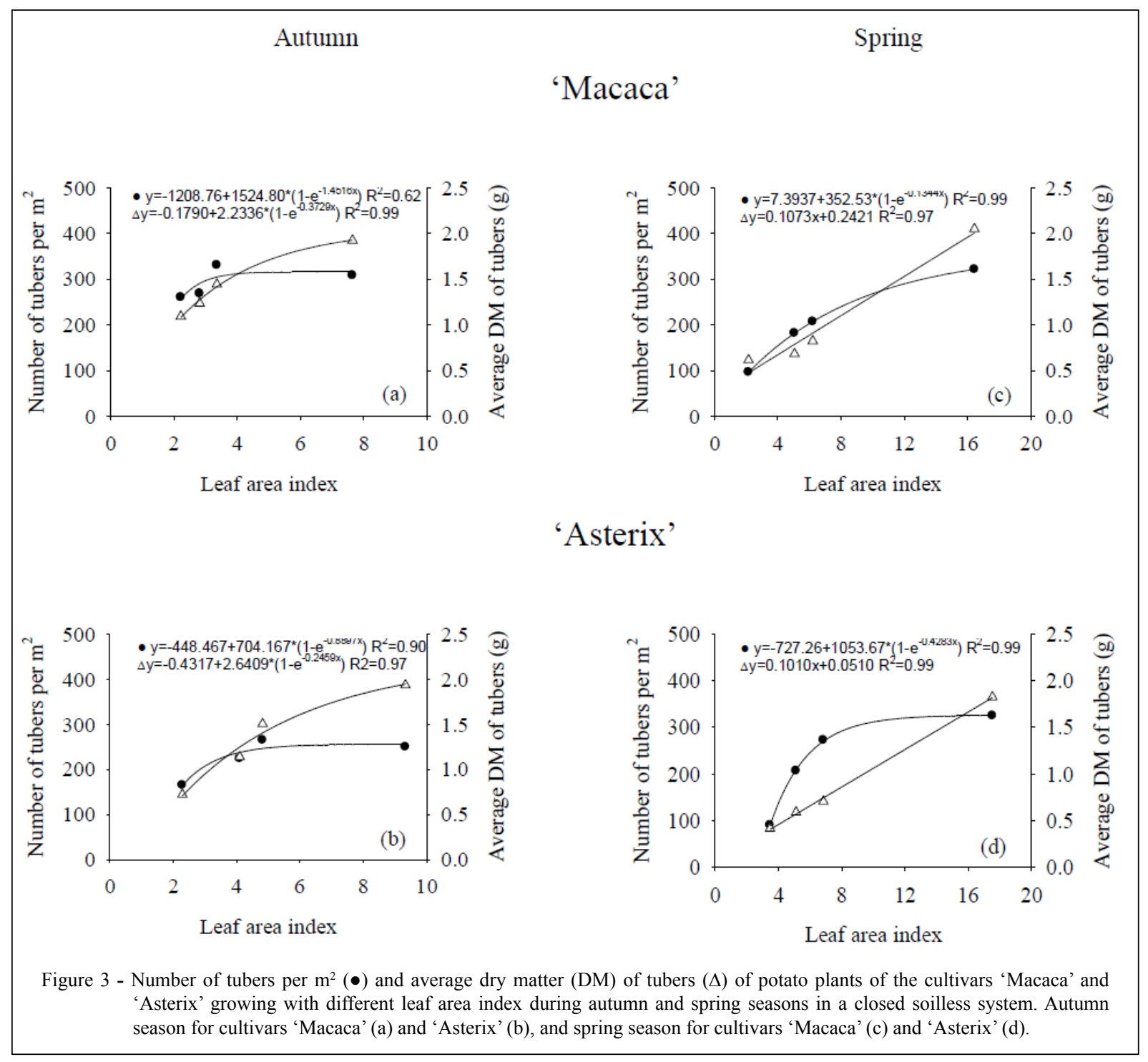

season, RUE had a linear response as LAI increased, reaching higher values of RUE for total dry matter production than in autumn. However, the highest RUE for the dry matter production of minitubers was in autumn, the growing season with lower availability of solar radiation, due to the higher harvest index (Figure 2). In the field, total and tuber dry matter were more affected by solar radiation interception, RUE decreased with increasing radiation intensity with plant growth. In the literature are found RUE values between 1.8 and $3.7 \mathrm{~g} \mathrm{DM} \mathrm{MJ}^{-1}$ to different locations and seasons (KOOMAN et al., 1996), similar to those found in this research in a soilless system.

In this study, shoot growth restriction by pruning was very effective to reduce LAI in a larger proportion than the reduction of both number and average dry matter of minitubers and the effectiveness of shoot growth restriction depended upon growing season. Considering an optimum LAI to maximize the dry matter production being from 3.5 and 4.5 (KHURANA \& MCLAREN, 1982), pruning potato plants at $30 \mathrm{~cm}$ was sufficient to keep the optimum LAI only during autumn season. In the average of both cultivars, pruning plants even at $20 \mathrm{~cm}$ reduced LAI from 16.9 to 5.1 during spring season, but also reduced number, average dry matter and harvest index of minitubers. Therefore, shoot growth restriction should be applied by pruning plants at $30 \mathrm{~cm}$ in both seasons, even resulting in higher LAI (6.5) during spring, because of the negative effects on harvest index and minituber production. Also, pruning plants had more effect on average dry matter than on number 
of minitubers and during spring than autumn seasons. Shoot growth restriction by pruning plants at $30 \mathrm{~cm}$ had no effect on harvest index and minituber number during autumn season with an average LAI of 4.1, but had a major effect on the average dry matter of minitubers during spring with an average LAI of 6.5. Reducing LAI is important because it has a direct relationship to the consumption of nutrient solution and chemical use to control foliar diseases, which is necessary to reduce costs of the production and increase quality of potato minitubers.

The linear increment of LAI can be associated to crop management of potato minituber production. In field conditions, potato plants are managed for high yield of tubers, so that plant density is adjusted to maximize LAI and the interception of solar radiation shortly after the beginning of tuberization. After this stage, tubers become the preferential sink of the plant. In soilless cultivation system, LAI increases after the beginning of tuberization and immature minitubers are harvested. Therefore, in soilless system there is a competition for assimilates between shoots and minitubers. It was showing in this experiment that the competition for assimilates is even higher in spring than in autumn season, because of environmental conditions that favors shoot growth. As a consequence, shoot remains as a main sink during minituber growth in spring season and shoot pruning should increase assimilate partitioning to sustain vegetative growth, which reduced harvest index and increased dry matter production of shoots.

Pruned shoots can be a source of stem cuttings for rooting and transplanting. Rooted stem cuttings offers a unique opportunity to produce high quality potato seeds without investing in tissue culture plantlets. If in an adequate population, rooted cuttings have higher yield than plants from tubers (ESCOBAR \& VANDER ZAAG, 1988). Besides pruning, other techniques, as shoot growth retardants (PAVLISTA,

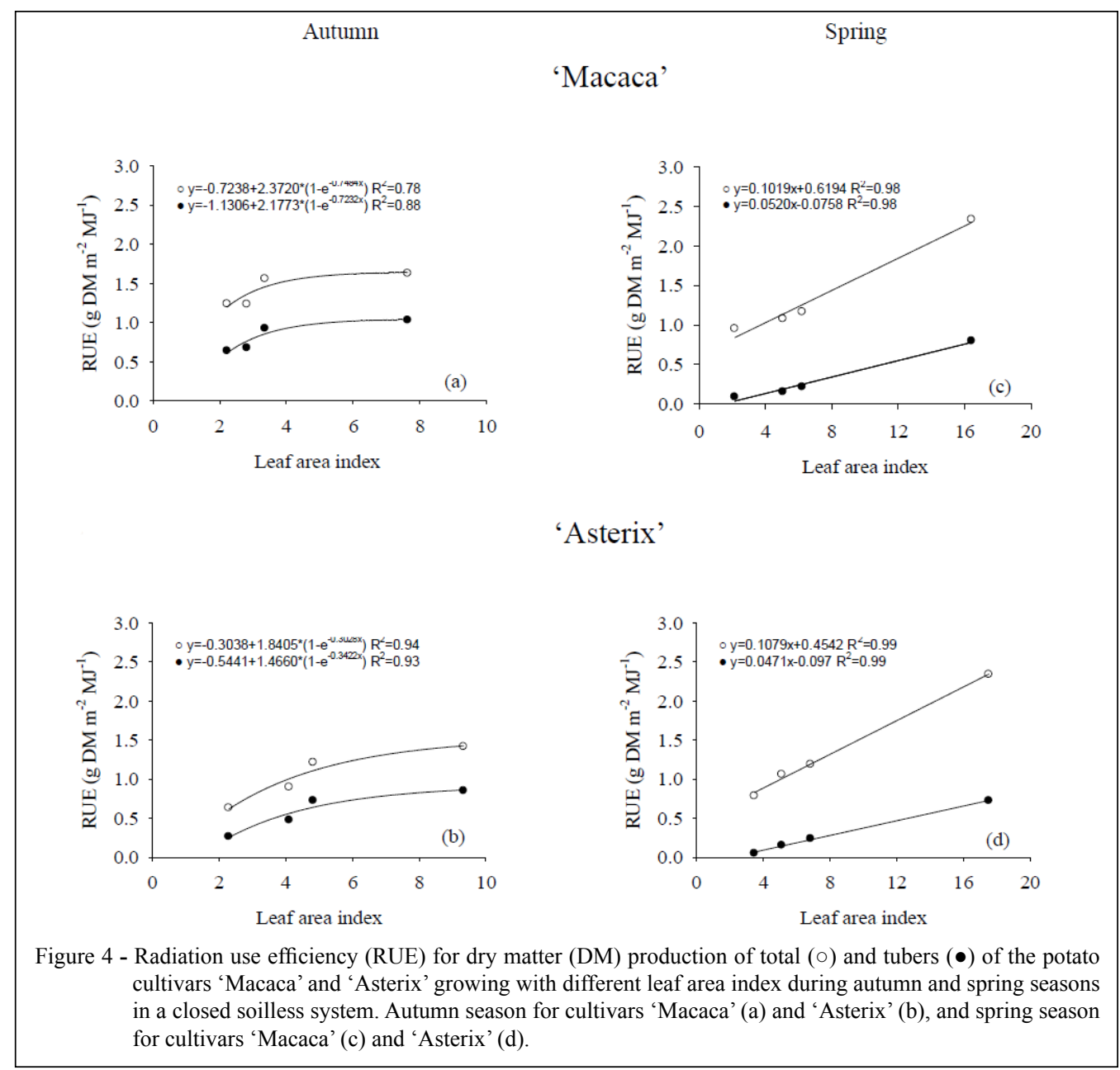

Ciência Rural, v.45, n.11, nov, 2015. 
2013) should be evaluated for the production of potato minitubers in soiless system, mostly for the spring season.

\section{CONCLUSION}

Pruning potato plants at $30 \mathrm{~cm}$ is a feasible technique to control leaf area index and it has lower effect on harvest index and number than in dry matter production of minitubers. Growth restriction does not change dry matter partitioning of potato plants grown in soilless system.

\section{REFERENCES}

BANDINELLI, M.G. et al. Concentração dos sais e da sacarose do meio MS na multiplicação in vitro e na aclimatização de batata. Horticultura Brasileira, v.31, n.2, p.242-247, 2013. Available from: <http://www. scielo.br/pdf/hb/v31n2/11.pdf>. Accessed: Mar. 27, 2014. doi: 10.1590/ S0102-05362013000200011.

BURIOL, G.A. et al. Transmissividade a radiação solar do polietileno de baixa densidade utilizado em estufas. Ciência Rural, v.25, n.1, p.1-4, 1995. Available from: <http://dx.doi.org/10.1590/S010384781995000100001>. Accessed: Oct. 22, 2012. doi:10.1590/S010384781995000100001 .

ESCOBAR, V.; VANDER ZAAG, E. Field performance of potato (Solanum spp.) cuttings in the warm tropis: influence of planting system, hilling, density and pruning. American Potato Journal, v.65, n.1, p.1-10, 1988. Available from: <http://link.springer.com/ article/10.1007\%2FBF02855308>. Accessed: Mar. 27, 2014. doi:10.1007/BF02855308.

ESTEFANEL, V. et al. Insolação e radiação solar na região de Santa Maria, RS. I - Estimativa da radiação solar global incidente a partir dos dados de insolação. Revista do Centro de Ciências Rurais, v.20, n.3-4, p.203-218, 1990. Available from: <http://coralx.ufsm.br/revista/ viewarticle.php?id=922>. Accessed: Oct. 22, 2012.

EWING, E.E. Heat stress and the tuberization stimulus. American Potato Journal, v.58, p.31-49, 1981. Available from: <http://www. springerlink.com/content/c724h866467w4341/>. Accessed: Oct. 21, 2012. doi:10.1007/BF02855378.

GULÍAS, J. et al. Relationship between maximum leaf photosynthesis, nitrogen content and specific leaf area in balearic endemic and nonendemic mediterranean species. Annals of Botany, v.92, p.215-222, 2003. Available from: <http://aob.oxfordjournals.org/content/92/2/215. full.pdf $>$. Accessed: Oct. 21, 2012. doi:10.1093/aob/mcg123.

KHEDHER, M.B.; EWING, E.E. Growth analyses of eleven potato cultivars grown in the greenhouse under long photoperiods with and without heat stress. American Potato Journal, v.62, p.537-554, 1985. Available from: <http://www.springerlink. com/content $/ 5032 \mathrm{t} 1 \mathrm{~m} 8 \mathrm{r} 7715340 />$. Accessed: Oct. 21, 2012. doi:10.1007/BF02854401.

KHURANA, S.C.; McLAREN, I.S. The influence of leaf area, light interception and season on potato growth and yield. Potato Research, v.25, p.329-342, 1982. Available from: <http://link.springer.com/article/10.1007/ BF02357290?null>. Accessed: Oct. 21, 2012. doi: 10.1007/BF02357290.
KOOMAN, P.L. et al. Effects of climate on different potato genotypes 1. Radiation interception, total and tuber dry matter production. European Journal of Agronomy, v.5, p.193-205, 1996. Available from: <http://www.sciencedirect.com/science/ article/pii/S116103019602031X>. Accessed: Oct. 21, 2012. doi: 10.1016/S1161-0301(96)02031-X.

MARINUS, J.; BODLAENDER, K.B.A. Response of some potato varieties to temperature. Potato Research,v.18,p.189-204, 1975.Available from: <http://www.springerlink.com/content/a103j1807m11n848/>. Accessed: Oct. 21, 2012. doi:10.1007/BF02361722.

MEDEIROS, C.A.B. et al. Produção de sementes pré-básicas de batata em sistemas hidropônicos. Horticultura Brasileira, v.20, n.1, p.110-114, 2002. Available from: <http://dx.doi.org/10.1590/S010205362002000100022>. Accessed: Oct. 22, 2012. doi:10.1590/S010205362002000100022 .

MÜLLER, D.R. et al. Produção hidropônica de batata em diferentes concentrações de solução nutritiva e épocas de cultivo. Pesquisa Agropecuária Brasileira, v.42, p.647-653, 2007. Available from: $<$ http://dx.doi.org/10.1590/S0100-204X2007000500006>. Accessed: Oct. 22, 2012. doi:10.1590/S0100-204X2007000500006.

OLIVEIRA, C.A.S. Potato crop growth as affected by nitrogen and plant density. Pesquisa Agropecuária Brasileira, v.35, n.5, p.939-950, 2000. Available from: $<$ http://dx.doi.org/10.1590/S0100-204X2000000500011>. Accessed: Oct. 22, 2012. doi:10.1590/S0100-204X2000000500011.

PAVLISTA, A. Influence of foliar-applied growth retardants on Russet Burbank potato tuber production. American Journal of Potato Research, v.90, n.4, p.395-401, 2013. Available from: <http://link. springer.com/article/10.1007\%2Fs12230-013-9307-2>. Accessed: Mar. 08, 2014. doi:10.1007/s12230-013-9307-2.

RITTER, E. et al. Comparison of hydroponic and aeroponic cultivation systems for the production of potato minitubers. Potato Research, v.44, n.2, p.127-135, 2001. Available from: <http://www.springerlink.com/content/ q211361701830511/>. Accessed: Oct. 22, 2012. doi:10.1007/BF02410099.

ROLOT, J.L.; SEUTIN, H. Soilless production of potato minitubers using a hydroponic technique. Potato Research, v.42, n.3-4, p.457469, 1999. Available from: <http://www.springerlink.com/content/ x3k5x782203r1053/>. Accessed: Oct. 22, 2012. doi:10.1007/BF02358162.

SANDRI, M.A. et al. High density of defoliated tomato plants in protected cultivation and its effects on development of trusses and fruits. Horticultura Brasileira, v.20, n.3, p.485-489, 2002. Available from: <http://dx.doi.org/10.1590/S0102-05362002000300018>. Accessed: Oct. 22, 2012. doi:10.1590/S0102-05362002000300018.

TREVISAN, R. et al. Uso de poda verde, plásticos refletivos, antitranspirante e potássio na produção de pêssegos. Pesquisa Agropecuária Brasileira, v.41, n.10, p.1485-1490, 2006. Available from: <http://dx.doi.org/10.1590/S0100-204X2006001000005>. Accessed: Oct. 22, 2012. doi:10.1590/S0100-204X2006001000005.

VAN DAM, J. et al. Effects of temperature and photoperiod on early growth and final number of tubers in potato (Solanum tuberosum L.). Potato Research, v.39, n.1, p.51-62, 1996. Available from: <http://www. springerlink.com/content/05854087674q46t1/>. Accessed: Oct. 22, 2012. doi:10.1007/BF02358206.

WRIGHT, J.L.; STARK, J.C. Potato. In: STEWART, B.A.; NIELSEN, D.R. (Eds.). Irrigation of agricultural crops. Madison: American Society of Agronomy, 1990. p.859-888. 